\title{
EVALUASI INTERGRATED MARKETING COMMUNICATION DISBUDPAR DAN DISPORAPAR DALAM MENYIAPKAN KOTA MALANG SEBAGAI TOURISM HUB TAHUN 2019-2020
}

\author{
${ }^{1}$ Nurul Pringgowati, ${ }^{2}$ Maulina Pia Wulandari, ${ }^{3}$ Rachmat Kriyantono \\ ${ }^{1,2,3}$ Program Studi Ilmu Komunikasi Universitas Brawijaya \\ Email : nurulleo@student.ub.ac.id
}

\begin{abstract}
Abstrak: Disbudpar 2019 dan Disporapar 2020 mengupayakan penerapan IMC dalam menyiapkan Kota Malang sebagai tourism hub. Namun, belum ada data empiris tentang bagaimana implementasi dari elemen IMC yang dilakukan. Tujuan penelitian ini adalah menganalisis dan mengevaluasi penerapan IMC dalam menyiapkan Kota Malang sebagai tourism hub. Menggunakan metodologi penelitian kualitatif melalui wawancara, observasi dan studi dokumen. Penelitian ini memanfaatkan IMC dalam menganalisis data penelitian. Hasil penelitian menunjukkan bahwa terdapat aktifitas implementasi IMC yang dilakukan oleh Disbudpar dan Disporapar, namun pada prosesnya perlu meningkatkan sinergi dan sosialisasi arah penerapan IMC kepada pelaku usaha wisata untuk membangun kesepahaman ekosistem pariwisata dalam proses pemasaran pariwisata menjadi tourism hub. Penelitian ini merekomendasikan peningkatan sinergitas model Pentahelix ABGCM dan melakukan pembinaan serta sosialisasi penerapan IMC kepada pelaku wisata.
\end{abstract}

Kata kunci : IMC, Marketing Communication, Tourism Hub, Kota Malang

\section{PENDAHULUAN}

Presiden Republik Indonesia dalam agenda rapat terbatas di awal tahun 2016 menetapkan bahwa pariwisata negara Indonesia menjadi sektor utama (leading sector) perekonomian (Alamsjah, 2016). Hal ini menjadi harapan masyarakat Indonesia dan tentunya pemerintah daerah setiap wilayah negara Indonesia karena memiliki potensi pariwisata yang bisa memberikan dampak positif bagi masyarakat. Berdasarkan data Badan Pusat Statistik (BPS), bahwa jumlah kunjungan wisatawan dari mancanegara ke Indonesia di tahun 2014-2018 tumbuh sebesar 67,6\% , hal ini sangat berpengaruh pada ketersediaan lapangan kerja bidang pariwisata mencapai 13 (tiga belas) juta orang pada tahun 2019 (Badan Pusat Statistik, 2020). Untuk mencapai target lebih besar, Pemerintah Indonesia berupaya terus melakukan pengembangan pariwisata dan adanya

Submitted: Januari 2021, Accepted: Februari 2020, Published: Juni 2021

ISSN: 2088-0626 (printed), ISSN: 2442-7365 (online) 
rencana pembangunan 10 (sepuluh) Bali baru atau 10 destinasi prioritas dengan menunjuk wisata Danau Toba (Sumatera Utara), Tanjung Kelayang (Kepulauan Bangka Belitung), Tanjung Lesung (Banten), Kepulauan Seribu (Jakarta), Borobudur (Jawa Timur), Bromo Tengger Semeru (Jawa Timur), Mandalika (NTB), Labuan Bajo (NTT), Wakatobi (Sulawesi Tenggara), Morotai (Maluku Utara) (Alamsjah, 2016) .

Diantara 10 Bali tersebut, ada wisata Bromo Tengger Semeru (BTS) di Jawa Timur, kemudian Pemerintah Indonesia memilih Kabupaten Malang sebagai daerah panyangga BTS (Anggraini, 2018), sehingga ini akan berpengaruh pada Kota Malang sebagai pusat transportasi Malang Raya. Sehingga membuat Pemerintah Kota Malang juga berupaya melakukan perbaikan dan pengembangan pariwisata agar wisatawan yang datang ke BTS bisa juga berkunjunga ke destinasi wisata yang disuguhkan oleh daerah penyangga.

Berawal dari Visi Pariwisata Kota Malang untuk menciptakan pariwisata yang Bersih, Makmur, Adil, Religius, Toleran Terkemuka, Aman, Berbudaya, Asri dan Terdidik (BERMARTABAT) pada tingkat nasional, dengan mewujudkan basis pariwisata Edukasi, Industri dan Budaya (Edutriya) kreatif dan inovatif sebagai bentuk sektor unggulan dari prioritas pembangunan daerah. Dari Visi tersebut muncul istilah menjadikan Kota Malang sebagai "Tourism hub" atau pusat pariwisata, yang kemudian oleh Bappeda Bidang Ekonomi menerjemahkan maksud dari tourism hub yakni memperbaiki ekosistem pariwisata. Tourism hub ini kemudian ditawarkan kepada destinasi wisata untuk melakukan perbaikan atau pembenahan diberbagai ekosistem wisata, ketika sudah siap akan dilakukan pengesahan Surat Keputusan (SK). Arah pembangunan pariwisata Kota Malang diatur dalam Peraturan Wali Kota Malang No. 34 Tahun 2014 tentang Rencana Induk Pengembangan Pariwisata Daerah (RIPPDA) dengan 
mambagi pembangunan menjadi tiga tahap mulai dari tahap I tahun 2010-2015, tahap II tahun 2016-2020, tahap III tahun 2021-2025 (2014).

Persiapan menjadi tourism hub berarti harus siap memberikan pelayanan wisata dan penawaran fasilitas kepada wisatawan. Sedangkan, wisatawan tentu memiliki beberapa alasan memutuskan untuk berkunjung pada sebuah destinasi wisata, mempertimbangkan fasilitas umum yang akan didapatkan. Sebuah wilayah atau kota layak disebut sebagai destinasi wisata menurut Cooper, Gilbert, dan Wanhill (1995), menyebutkan ada beberapa faktor mulai dari kehadiran atraksi (attraction) sebagai seni atau aksi yang bisa ditunjukkan kepada wisatawan, aksesbilitas (accessibilities) transportasi yang memadai, fasilitas (amenities) yang lengkap mulai dari ketersediaan rumah makan, penginapan, agen perjalanan, dan ancillary service atau adanya DMO (Destination Marketing Organization) seperti biro perjalanan wisata untuk memudahkan wisatawan memilih penawaran wisata yang diinginkan, sehingga tidak terjadi kebingungan meskipun berkunjung ke lokasi wisata untuk pertama kalinya. Faktor-faktor tersebut dimiliki Kota Malang yang memiliki branding sebagai Kota Wisata dengan suhu udara dingin sangat cocok cocok sebagai destinasi wisata atau tujuan berlibur.

BPS tahun 2020 merilis data naiknya jumlah wisatawan pada tahun 2014 hingga 2019, jumlah wisatawan nusantara pada tahun 2014 berjumlah 2,423,076 orang naik menjadi 5,170,523 orang pada tahun 2019, dan untuk wisatawan mancanegara berjumlah 6,025 orang di tahun 2014, naik menjadi 16,286 orang di tahun 2019 (Badan Pusat Statistik, 2020). Data tersebut menunjukkan kenaikan secara signifikan pada jumlah wisatawan yang datang, dan puncaknya pada tahun 2019. Kunjungan wisatawan yang tinggi, menambah peluang pekerjaan baru dan transaksi di masyarakat, sehingga berpengaruh pada Pendapatan Asli Daerah (PAD). Meskipun 
dikenal sebagai kota wisata, namun pariwisata Kota Malang belum menjadi sektor unggulan untuk PAD. Pernyataan tersebut berdasarkan data yang BPS Kota Malang tahun 2020 dan peneliti merangkum ada lima sektor unggulan termasuk pariwisata pada urutan kelima yang masuk dalam bidang akomodasi dan makan minum. Rincian angka dan urutan sebagai berikut : 1) Perdagangan besar eceran dan reparasi kendaraan bermotor (29,46\%); 2) Industri pengolahan $(25,75 \%)$; 3) Konstruksi (12,61\%); 4) Jasa pendidikan (8,10\%); 5) Akomodasi dan makan minum (4,98\%) (Badan Pusat Statistik, 2020).

Pariwisata Kota Malang belum berkontribusi lebih kepada penghasilan masyarakat, pentingnya perbaikan pada bidang pariwisata selain bidang industri dan bidang destinasi wisata, yang tidak kalah penting adalah bidang pemasaran pariwisata karena kinerja pemasaran pariwisata sangat berpengaruh pada ketertarikan serta keputusan wisatawan untuk berwisata ke Kota Malang. Bebarapa penelitian terdahulu yang dilakukan dilakukan di lingkup Kota Malang seperti yang dilakukan oleh Muhammad Danang Setioko (2019), menghasilkan bahwa destinasi wisata di Kota Malang lebih mengedepankan pada wisata MICE, kuliner, pendidikan dan religi karena keterbatasan ruang kota untuk dijadikan destinasi wisata. Dimas Arif R., Ni Made Ariani, dan Ni Nyoman Sri A. (2017) melakukan penelitian tentang kualitas atraksi dari event Malang Flower Carnival dengan hasil bahwa wisatawan cukup tertatik untuk menjadikan event carnival sebagai atraksi yang menarik. Keduanya lebih menekankan pada pengembangan destinasi wisata.

Selanjutnya, penelitian tentang branding Kota Malang sebagai Kota Wisata oleh Pransiskus Albert dan Sulih Indra Dewi (2019) yang menghasilkan Kota Malang telah melakukan strategi brand positioning mulai dari city branding, brand identity, brand personality, brand communication, brand equity, namun ada kritik yang disampaikan tentang logo Beautiful Malang 
dianggap kurang mencerminkan citra sebagai Kota Wisata hingga masalah dana, prasaran, dan kurang kesadaran pariwisata. Dari berbagai penelitian terdahulu lebih menekankan pada pengembangan destinasi wisata, atraksi dan sedikit yang membahas tentang promosi, padahal penting untuk mengetahui faktor lain penyebab pariwisata dinilai kurang berkembang seperti dari pespekstif pemasaran pariwisatanya.

Mengacu pada RIPPDA Kota Malang, pengertian pemasaran pariwisata merupakan seluruh rangkaian proses dalam menciptakan, mengkomunikasikan dan menyampaikan pesan produk wisata serta mengelola relasi wisatawan dalam pengembangan pariwisata dan seluruh stakeholder. Diluar Kota Malang banyak peneliti sudah mulai melihat sudut lain dari pengembangan pariwisata yakni tentang pemasaran pariwisata yang mulai menerapkan komunikasi pemasaran terpadu (IMC). IMC dalam perusahaan berusaha mengintegrasikan dan mengkoordinasikan berbagai saluran komunikasi dalam menyampaikan pesan berkaitan dengan perusahaan dan produk yang ditawarkan (Yeshin, 1998).

Duncan (2002) berpendapat IMC bisa mendorong value dari sebuah branding lebih terarah, sehingga mampu menciptakan hubungan yang menguntungkan antara stakeholder dan consumer. Mengedepankan proses komunikasi yang menjadi jantung dari seluruh relasi sekuler sehingga kolaborasi elemen IMC diperlukan (Mulayana \& Harjanto, 2008). Yeshin (1998) menyebutkan terdapat tujuh elemen dari IMC yang perlu dipadukan antara lain Advertising, Media masa, Sales promotion, Direct marketing, Public Relation, Sponsorship, Corporate communication, pada perkembangannya Pickton dan Broderick (2005), menambahkan elemen Exhibitions and trade show dan Online marketing oleh Tjiptono dan Chandra (2008). Teori IMC 
lebih berfokus pada proses komunikasi pemasaran terintegrasi mencakup sosialisasi, menciptakan relasi baik melalui pesan-pesan konsisten untuk meningkatkan branding value.

Penelitian yang dilakukan oleh Sobari dan Haryanti (2017) tentang Implementasi IMC di Provinsi Banten menghasilkan selain melakukan promosi dengan iklan dan city branding juga adanya kerja sama dengan berbagai stakeholder pariwisata di Banten. Penelitian yang sama juga dilakukan oleh Betari Avinda, I Nyoman Sudiarta dan Ni Made (2016) di Banyuwangi, menghasilkan adanya penerapan IMC namun kurang efektif, sehingga ada beberapa evaluasi mulai dari memperkuat sales promotion, public ralations dan meningkatkan kerja sama dengan stakeholder pariwisata. Dari penelitian tersebut, menunjukkan bahwa ada faktor komunikasi pemasaran yang turut mempengaruhi keberhasilan pariwisata. Sehingga pentingnya melakukan penelitian komunikasi pemasaran pada suatu kota yang menjadikan pariwisata sebagai sektor unggulannya termasuk di Kota Malang yang belum ada penelitian dilakukan berdasarkan perspektif komunikasi pemasaran dengan penerapan IMC.

Untuk mencapai tujuan sebagai tourism hub, Pemkot Malang melalui Dinas Budaya dan Pariwisata (Disbudpar) 2019 yang pada awal tahun 2020 mengalami perubahan struktur menjadi Dinas Pemuda, Olahraga dan Pariwisata (Disporapar) 2020 mulai merancang strategi pemasaran pariwisata yang dinilai akan efektif diterapkan berdasarkan kondisi internal dan eksternal dari potensi Kota Malang. Jika mengacu pada arahan Kementrian Pariwisata Republik Indonesia Nomor 14 Tahun 2016 tentang Pariwisata Berkelanjutan, pemerintah RI menggunakan konsep pembangunan organisasi manajemen destinasi yang melibatkan unsur stakeholder Penta helix ABGCM (academic, business, governance, community, media) (2016), dan secara keseluruhan Kota Malang memiliki semua stakeholder pariwisata tersebut, sehingga diharapkan pada proses 
ilmplementasi strategi menggunakan IMC yang dilakukan oleh Disbudpar dan Disporapar perlu melibatkan seluruh stakeholder ABGCM. Namun, belum ada data empiris tentang implementasi IMC pada proses pemasaran pariwisata yang dilakukan oleh Disbudpar dan Disporapar.

Rumusan masalah yang terbangun adalah bagaimana implementasi strategi komunikasi pemasaran terpadu (IMC) yang diterapkan oleh Disbudpar dan Disporapar dalam menyiapkan Kota Malang sebagai tourism. Sehingga tujuan penelitian ini untuk menganalisis dan mengevaluasi penerapan IMC berdasarkan hasil wawancara, observasi dan studi dokumen.

\section{METODE}

Penelitian ini menggunakan metodologi penelitian kualitatif untuk melihat realitas pada Disbudpar dan Disporapar. Metodologi penelitian kualitatif menurut Kriyantono (2014), menggunakan pendekatan interpretatif dengan konstruksi sosial bersifat relativ yang dipengaruhi oleh konteks pengalaman dan waktu. Daymon dan Holloway (2011) menambahkan jika menggunakan metodologi kualitatif cenderung pada subjektivitas dari realitas sosial sehingga memiliki kemampuan yang baik pada pemahaman dan berbagai perspektif terhadap masyarakat dalam ranah objek penelitian. Penelitian ini bertujuan mengkaji strategi IMC oleh Disbudpar dan Disporapar dalam menyiapkan Kota Malang sebagai tourism hub 2019-2020. Untuk menjawab tujuan dari penelitian, peneliti menganalisis dan mengevaluasi sejauh mana proses implementasi sesuai dengan target yang direncanakan berdasarkan hasil dari metode pengumpulan data wawancara, oberservasi dan studi dokumen.

Peneliti telah melakukan wawancara kepada 5 (lima) Informan yang terdiri : 1) R. Agung Harjaya Buana, SE, M.SE (informan 1) selaku Kepala Seksi Pemasaran Pariwisata Disbudpar 2019; 2)Ratih Sulistyo Handayani, ST,M.Si (informan 2) selaku Kepala Seksi Promosi dan Brand 
Pariwisata Disporapar 2020; 3)Isa Wahyudi, S.Psi., M.Psi (informan 3) selaku Ketua Forkom Pokdarwis Kota Malang; 4)Muhammad Rosyidi (informan 4) selaku Pembina Pokdarwis Kampung Warna-warni Jodipan; 5) Devi Arif Nurhadyanto (informan 5) selaku Ketua Pokdarwis Kampung Gribig Religius.

\section{HASIL}

Daya tarik wisata di Kota Malang meliputi wisata kuliner, wisata kampung-kampung tematik, wisata belanja, Disbudpar dan Disporapar Kota Malang mengupayakan pemasaran pariwisata sebagai bentuk usaha pembangunan pariwisata dengan melakukan berbagai usaha komunikasi melalui promosi dan mengadakan berbagai kegiatan kepariwisataan. Untuk mengetahui respon atau kinerja dari pelaksanaan strategi, dilakukan konfirmasi kepada salah satu stakeholder pariwisata yakni Pokdarwis.

\section{Aktifitas Direct Marketing}

Kegiatan direct marketing yang dilakukan oleh Disbudpar dan Disporapar diwujudkan dengan mengadakan berbagai event festival dan pameran dagang, sehingga antara peserta kegiatan dengan wisatawan bisa terjadi interaksi dan memberikan pengalaman langsung. Peran Disbudpar dan Disporapar Kota Malang sebagai fasilitator untuk mempertemukan penawaran dan harapan sesuai dengan keinginan wisatawan. Pada kegiatan ini, sebenarnya Disbudpar dan Disporapar bisa memiliki database dari peserta kegiatan, namun sementara hanya digunakan sebagai dokumen acara dan tidak ada tindak lanjut, atau menggunakan database-driven messaging system untuk melakukan berbagai promosi pariwisata.

\section{Aktifitas Sales Promotion}


Pada kegiatan sales promotion, Disbudpar dan Disporapar sebagai fasilitator bertugas melakukan pembinaan kepada pelaku wisata. Peneliti menemukan adanya penawaran paket wisata yang dilakukan oleh lembaga pariwisata swasta, agen perjalanan wisata dengan destinasi wisata di Kota Malang. Penawaran paket wisata yang dilakukan oleh agen perjalanan wisata seperti wisata Bromo 2 Day 1 Night (2 hari 1 malam), dengan harga paket wisatawan bisa berlibur menikmati wisata gunung Bromo dan wisata air terjun sebagai bonus pilihan wisata.

\section{Aktifitas Personal Selling}

Personal selling dilakukan melalui berbagai kegiatan yang diselenggaran oleh Disbupar dan Disporapar seperti kegiatan Meeting, Incentives, Conventions dan Exhibitions (MICE), Malang Travel Mart (MTM) yang mempertemukan seller (pelaku wisata dari Malang Raya) dengan buyer (pelaku wisata dari luar Malang Raya) tujuannya untuk membuka pintu kerja sama diantara keduanya. Melalui kegiatan tersebut, penjual memiliki keahlian untuk berinteraksi dan melakukan komunikasi dua arah kepada wisatawan. Kemudian, Disbudpar dan Disporapar juga melakukan pelatihan pemandu wisata dengan mengundang pemateri yang berpengalaman kepada pengelola destinasi wisata untuk membentuk kecakapan dalam memandu wisata. Selain itu, Kota Malang juga memiliki Kakang-Mbakyu sebagai Duta Wisata yang dibentuk oleh Disbudpar dan Disporapar, keahlian komunikasi dari Duta Wisata bisa dimanfaatkan untuk melakukan personal selling pada saat event-event besar Kota Malang. Menurut informan 4, kehadiran dari KakangMbakyu belum berkontribusi penuh pada pariwisata terlebih perannya untuk destinasi wisata, karena dinilai hanya sebagai agenda pemerintah saja.

\section{Aktifitas Sponsorship}


Pada kegiatan sponsorship, peneliti menemukan bahwa Disbudpar dan Disporapar Kota Malang berkerja sama dalam pendanaan event festival bersama tingkat Malang Raya bersama Kota Batu dan Kabupaten Malang. Seperti kegiatan Malang Flower Carnival (MFC) yang melibatkan Malang Raya, dalam kegiatan tersebut ketiga daerah terlibat kerjasama pembagian dana secara internal dan saling melakukan publikasi masing-masing. Selain itu, pada tingkat wisata lokal, berdasarkan data wawancara bersama informan dari pengelola Pokdariwis, Disbudpar dan Disporapar diudang untuk mendukung secara moril dan mengsahkan event yang terselenggara.

\section{Aktifitas Advertising}

Upaya pemasaran ini tentu tidak lepas dari usaha melakukan advertising atau periklanan, Disbudpar dan Disporapar terus melakukan pengenalan produk wisata apa saja yang ada di Kota Malang melalui media sosial Intagram “@malang.menyapa” yang memuat informasi jadwal avent yang diadakan pemerintah dan destinasi wisata. Selain itu, membuat pamphlet dan peta lokasi wisata, membuat booklet destinasi wisata dan buku kampung wisata tematik di Kota Malang yang bekerja sama dengan penulis dari media berita online kompasiana. Namun, disisi lain dari tiga informan pengelola Pokdariwis merasa tidak ada sosialisasi terkait langkah periklanan seperti apa yang perlu dilakukan oleh destinasi wisata dan ada usulan untuk Disbudpar dan Disporapar, agar melakukan promosi periklanan dengan menggunakan video tron yang diposisikan di sudut-sudut Kota Malang, agar tidak selalu iklan rokok yang menonjol dilihat masyarakat, melaikan iklaniklan pariwisata Kota Malang. 


\section{Aktifitas Corporate Communications}

Pamphlet, peta wisata, brosur dan buku, selain memuat konten advertising atau periklanan wisata di Kota Malang juga sebagai bentuk kegiatan corporate communication. Melakukan publisitas press release dan merangkul berbagai media massa untuk mempertahankan citra Kota Malang sebagai kota wisata. Membuat media sosial Instagram “@malang.menyapa” untuk lebih dekat dengan masyarakat dan pembuatan calender of event juga dilakukan oleh Disbudpar dan Disporapar sebagai bentuk nyata jadwal event pariwisata di Kota Malang yang direkomendasikan untuk dikunjungi wisatawan.

\section{Aktifitas Exhibitions and Trade show}

Untuk memberi penawaran produk wisata atau meberikan berbagai atraksi pariwisata, Disbudpar Kota Malang Exhibitions dan trade show melalui event Malang travel mart, Malang flower carnival, Festival Batik Ngalam, Malang fashion week. Berdasarkan data wawancara bersama Informan dari pengelola Pokdarwis kampung wisata tematik, peneliti menemukan adanya keperluan fasilitas membangun gedung convention sebagai bentuk fasilitas bagi para pelaku usaha wisata dan UMKM melakukan pameran produk atau exhibitions, sehingga mampu menekan pendanaan dalam promosi yang dilakukan oleh pelaku wisata.

\section{Aktifitas Online Marketing}

Disbudpar pernah memiliki aplikasi "Malang Menyapa" sebagai aplikasi yang memberi informasi tentang pariwisata di Kota Malang mulai rute lokasi, transportasi, restoran, hotel atau penginapand 
dan usaha pendukung wisata lainnya. Launching pada tahun 2017 dan mulai dipromosikan diberbagai event nasional, dan memperoleh penghargaan pada Anugrah Pesona Indonesia (API). Namun, berjalannya waktu, aplikasi ini dinilai tidak melakukan upgrade pada informasi-informasi terbaru wisata Kota Malang, sehingga pada akhir tahun 2019 mulai di non-aktifkan dan dihapus dari Playstore. Penting eksistensi produk online marketing juga harus diimbangi dengan kebaharuan data dan informasi. Menurut 3 informan dari pengelola Pokdarwis, diranah Pokdarwis masih banyak kekurangan SDM yang menguasai online marketing dan mengharapkan dari pihak Pemerintah Kota Malang melakukan pelatihan untuk meningkatkan SDM.

\section{Aktifitas Public Relations}

Mempertahankan citra sebagai kota wisata, dengan terlibat mengadakan festival dan event pariwisata sebagai kerja public relations untuk membentuk corporate identity. Kegiatan MICE, publisitas press release, kerjasama media massa dilakukan oleh Disbudpar dan Disporapar. Public relations juga menjalin relasi baik dengan stakeholder untuk menyatukan dan berkolaborasi dalam perencanaan dan implementasi strategi, termasuk adanya perencanaan melakukan rebranding dan rencana pemasaran pariwisata yang tentu perlu melibatkan banyak stakeholder untuk turut memberi pendapat dan saranya. Pembentukan Kakang-Mbakyu sebagai duta wisata dimanfaatkan untuk bisa melakukan personal selling dan mampu berkomunikasi dengan stakeholder ataupun khalayak dalam memperkenalkan wisata di Kota Malang. Sebagai bentuk pemasaran wisata, tentu tidak lepas dari kegiatan advertising, maka Disbudpar dan Disporapar melalui advertising menyampaikan komunikasi atau pesan-pesan public relations dalam melakukan promosi. Berdasarkan observasi peneliti, Kota Malang sangat minim akan tourist information center, 
padahal sebagai kota wisata tentu akan sangat dibutuhkan karena ini berhubungan dengan wisatawan lokal maupun internasional, sehingga diperlukan peningkatan jumlah tourist information center sebagai bentuk palayanan fasilitas pariwisata.

\section{DISKUSI}

Hasil penelitian menunjukkan adanya aktifitas dari implementasi IMC yang dilakukan oleh Disbudpar dan Disporapar. Namun, beberapa elemen dari IMC belum sepenuhnya dilakukan dengan maksimal, karena belum ada seorang yang sepenuhnya menguasai IMC sehingga belum bisa memanfaatkan dan mengkolaborasikan setiap elemennya. Disbudpar dan Disporapar yang menjadi fasilitator atau pengarah (directur) dalam melakukan direct marketing sudah membantu mempertemukan pelaku usaha wisata dengan wisatawan agar terjadi interaksi langsung (face to face) di event-event yang terlaksana, namun beberapa cara direct marketing lain belum dilakukan dengan baik, sedangkan dalam melakukan direct marketing perlu mengetahui komponen, media atau channel yang digunakan, dan cara melakukan direct marketing untuk berbeda generasi (Prasetyo et al., 2018).

Dinas yang merangkul media massa untuk melakukan membantu membangun citra melalui berita-berita yang disampaikan, namun seperti pendapat Kriyantono (2019), bahwa media massa bisa memberitakan positif dan juga bisa memberitakan negatif karena tidak dikonfirmasi kebenarannya. Belum sepenuhnya diketahui bagaimana langkah pastinya oleh destinasi wisata dan direct marketing seperti apa agar tercapai sesuai segmentasinya. Maka, penguasaan IMC dan pola pikir yang menjadi hambatan, seharusnya segera untuk diatasi agar tidak terjadi kebingungan pada pengelola destinasi wisata. Pendapat Pickton dan Broderick (2005) tentang implementasi IMC 
terbilang sulit karena proses tidak sesuai target, benar-benar menjadi tantangan untuk Disbudpar dan Disporapar.

Dibeberapa kegiatan tentu ada data pengunjung dari hasil absensi atau daftar hadir, atau juga diperoleh dari menghubungi media, lalu melalui data tersebut kegiatan direct marketing untuk melakukan database-driven messaging system belum terlaksana dilingkup destinasi wisata karena kurangnya pemahaman fungsi dari database. Termasuk kegiatan online marketing dan corporate identity memanfaatkan internet dengan banyak fitur untuk penyebaran informasi secara global, website dan instagram sebagai salah satu bentuk komunikasi dengan prinsip interaktif (Kriyantono, 2020) dan mendapat respon untuk menciptakan citra perusahaan (Tjiptono \& Chandra, 2008).

Keberadaan pariwisata di Kota Malang tidak akan menarik perhatian tanpa kegiatan advertising yang memuat informasi ditambah personal selling untuk meyakinkan wisatawan. Prinsip-prinsip dari personal selling memuat kemampuan dalam bernegosiasi dan hubungan atau ralasi dalam pemasaran (Kotler, 2002). Disbudpar dan Disporapar memiliki Kasi Pemasaran pariwisata yang bergerak untuk pembinaan Kakang-Mbakyu, pemandu wisata dan lembaga pariwisata. Meskipun terbilang lingkup besar di pemerintahan, namun Disbudpar bisa memberi arahan atau pelatihan kepada pelaku wisata tentang tugas melakukan personal selling.

Disisi lain peluang untuk melakukan CSR bagi perusahaan juga terbuka lebar, dengan banyaknya kampung-kampung yang akan dijadikan lokasi wisata di Kota Malang, sebagaimana dengan hasil penelitian tentang Humas dan tanggung jawab sosial perusahaan di era mandatory approach di Indonesia yang dilakukan oleh Kriyantono (2015b), menyatakan perusahaan bisa melakukan CSR sebagai bentuk tanggung jawab public relation untuk memperoleh reputasi 
dengan mewujudkan kesejahteraan masyarakat, dan Pemkota Malang bisa mempromosikan kepada perusahaan sekaligus menawarkan program. Seperti halnya, PT. Inti Daya Guna Aneka Warna (INDANA) yang melakukan program CSR di kampung wisata warnna-warni Jodipan.

Keberhasilan dari IMC yang dipengaruhi oleh kemampuan menjalin relasi dengan baik dengan stakeholder pariwisata melalui kegiatan public relations dan corporate identity, keduanya sangat erat hubunganya dengan elemen-elemen IMC lainnya. Menggunakan pesan sosialiasasi yang disampaikan melalui berbagai media seperti mengadakan event-event masyarakat di Kota Malang, menurut Kriyantono (2017) pendekatan kearifan lokal ini dilakukan dalam membangun komunikasi dan ralasi dilingkungan stakeholder. Pendekatan dengan kekeluaragaan dilakukan dalam proses penyelesaian masalah di destinasi wisata Kota Malang, seperti silahturahim dan musyawarah sehingga masalah bisa terselesaikan karena kedekatan satu sama lain untuk saling memahami(Kriyantono \& Sa’diyah, 2018).

Disbudpar dan Disporapar, melalui berbagai event dan festival, merangkul media pemberitaan, berupaya mempertahankan citra sebagai Kota wisata. Hal tersebut sependapat dengan penelitian tentang pembentukan branding Kota Malang sebagai Kota Wisata (Albet \& Dewi, 2019), yang melakukan berbagai cara pembentukan citra oleh Disbudpar 2019. Dalam hal ini sebenarnya diharuskan berkolaborasi semua stakeholder dan tidak individual, karena komunikasi yang dibangun ada dimana-mana (ubiquity) dan kapan saja seperti darah yang mengalir pada sebuah organisasi untuk bisa berkoordinasi dan bekerja sama (Kriyantono, 2018).

Kegiatan public relation erat hubungannya dengan penelitian atau riset untuk merencanakan program, termasuk pemerintah Kota Malang yang telah melakukan riset untuk pembangunan wisata di Kota Malang tertuang dalam Peraturan Walikota Malang Nomor 40 Tahun 
2015 tentang Rencana Pembangunan Jangka Menengah Daerah ( RPJMD ) Kota Malang tahun 2016. Tujuannya untuk mengoprasionalkan RPJMD lebih terukur dan jelas (2015). Selaras dengan pendapat Kriyantono (2015a) bahwa riset akan membantu kegiatan public relation berjalan sesuai prosedur ilmiah, tidak hilang arah, tidak memperkirakan atau hanya mengandalkan intuisi.

Disisi lain, penelitian ini membuktikan juga bahwa keberadaan wisata kampung tematik mulai dikembangkan oleh Disbudpar Kota Malang dengan memanfaatkan pemukiman, menggali potensi setiap wilayah dan dijadikan wisata kampung tematik. Tidak selaras dengan salah satu hasil penelitian dilakukan oleh Muhammad Danang Setioko (2019) yang mengatakan bahwa perwilayahan destinasi wisata di Kota Malang sudah tidak bisa digali lagi karena padatnya pemukiman.

\section{KESIMPULAN}

Terdapat aktifitas IMC yang dilakukan oleh Disbudpar dan Disporapar. Namun pada prosesnya kurang melakukan sosialisasi yang melibatkan banyak stakeholder pariwisata dalam perencanaan strategi, sehingga baik Disbudpar dan Disporapar sebagai leader perlu menguasai IMC dalam perencanaan membangun ekosistem pariwisata menuju tourism hub di Kota Malang. Sehingga, teori IMC yang berfokus pada proses komunikasi pemasaran terintegrasi mencakup sosialisasi, menciptakan relasi baik melalui pesan-pesan yang konsisten bisa diimplementasikan dengan baik.

Penelitian ini merekomendasikan peningkatan sinergi organisasi manajemen destinasi model Penta helix ABGCM (academic, business, governance, community, media), bahwa dalam pelaksanakan IMC diperlukan keterlibatan dan integrasi unsur Penta helix ABGCM sebagai bentuk koordinasi pada perencanaan strategi dan implementasinya pengelolaan pariwisata yang 
berkelanjutan. Pemerintah melalui Disbudpar dan Disporapar perlu melakukan sosialisasi startegi komunikasi pemasaran pariwisata dan pembinaan kepada pengelola destinasi wisata agar mengerti langkah-langkah yang perlu diimplementasikan. IMC yang mulai diperhatikan oleh organisasi, dalam praktiknya memang sangat sulit untuk dipastikan apakah IMC benar-benar terintegrasi karena memiliki keberhasilan yang beragam, namun ini bukan menjadi alasan untuk mencoba karena dampak dari sinergi dan koherensinya keutungannya sangat besar.

\section{DAFTAR PUSTAKA}

Alamsjah, M. I. (2016). Kementrian Pariwisata Republik Indonesia. Jakarta.

Albet, P., \& Dewi, S. I. (2019). Strategi branding Dinas Kebudayaan dan Pariwisata Kota Malang dalam membentuk image sebagai Kota Pariwisata. Jurnal Komunikasi Nusantara, 1(2), 107-115. https://doi.org/10.33366/jkn.v1i2.27

Anggraini, P. (2018). Kabupaten Malang Terpilih Jadi Gawang Wisata Nasional, Begini Kesiapannya. Retrieved December 1, 2020, from https://malangtimes.com/baca/29915/20180731/003000/kabupaten-malang-terpilih-jadigawang-wisata-nasional-begini-kesiapannya

Avinda, C. B., Sudiarta, I. N., \& Karini, N. M. O. (2016). Strategi promosi Banyuwangi sebagai destinasi wisata ( studi kasus pada Dinas Kebudayaan dan Pariwisata ). In Jurnal Industri Perjalanan Wisata (Vol. 4). https://doi.org/10.24843/IPTA.2016.v04.i01.p10

Badan Pusat Statistik. (2020). Kota Malang dalam Angka, Malang Municipality in Figures 2020. Kota Malang.

Cooper, J., Gilbert, D., \& Wanhill., S. (1995). Tourism, principles and practice. In Tourism: Principles and Practice. London. London: Logman.

Daymon, C., \& Holloway, I. (2011). Qualitative research methods in public relations and marketing communication (Second Edi). New York: Routledge.

Duncan, T. (2002). IMC : Using advertising and promotion to build brand. McGraw-Hill Publishing Companiesl.

Kementrian Pariwisata RI. (2016). Peraturan Menteri Pariwisata Republik Indonesia Nomor 14 tahun 2016 tentang Pedoman Destinasi Pariwisata Berkelanjutan. Jakarta.

Kotler, P. (2002). Manajemen pemasaran, analisa perencanaan, implementasi dan kontrol. Jakarta: Prehalindo.

Kriyantono, R. (2014). Teknik praktis riset komunikasi. Jakarta: Kencana. 
Kriyantono, R. (2015a). Public relations, issue \& crisis management: Pendekatan critical public relation, etnografi kritis \& kualitatif. Jakarta: Kencana.

Kriyantono, R. (2015b). Public relations and corporate social responsibility in mandatory approach era in Indonesia. Procedia - Social and Behavioral Sciences, 211(9), 320-327. https://doi.org/10.1016/j.sbspro.2015.11.041

Kriyantono, R. (2017). Teori-teori public relations perspektif barat \& lokal: Aplikasi penelitian \& praktik. Jakarta: Kencana.

Kriyantono, R. (2018). Meneropong praktik public relations di Indonesia dengan teori dan riset. Kota Malang: Universitas Brawijaya Press.

Kriyantono, R. (2019). The implementation of the regulation of the Minister of Administrative Reform and Bureaucratic Reform No 29/2011 in crisis management of government public relations. Jurnal Komunikator, 11(2), 93-106. https://doi.org/10.18196/jkm.112023

Kriyantono, R. (2020). Efektivitas website perguruan tinggi negeri sebagai penyedia informasi bagi mahasiswa. Jurnal Studi Komunikasi, 4(1), 117. https://doi.org/10.25139/jsk.v4i1.1799

Kriyantono, R., \& Sa'diyah, H. (2018). Kearifan lokal dan strategi komunikasi public relations di BUMN dan perusahaan swasta. Jurnal Ilmu Komunikasi, 15(2), 171. https://doi.org/10.24002/jik.v15i2.1480

Mulayana, D., \& Harjanto, R. (2008). Komunikasi getok tular pengantar popularitas merek. Jurnal Komunikasi, 9(2), 233-242. https://doi.org/10.29313/mediator.v9i2.1131

Pickton, D., \& Broderick, A. (2005). Integrated marketing communications. Hant: Ashford Colour Press.

Prasetyo, B. D., Febriani, N. S., Asmara, W. W., Tamitiadini, D. D., Destrity, N. A., Avina, D. A. A., \& Illahi, A. K. (2018). Komunikasi pemasaran terpadu: pendekatan tradisional hingga era media baru. Malang: Universitas Brawijaya Press.

Rachman, D. A., Ariani, N. M., Nyoman, N., \& Aryanti, S. (2017). Persepsi pengunjung terhadap kualitas event Malang flower carnival ( MFC ) sebagai atraksi wisata di Kota Malang. In Jurnal Kepariwisataan dan Hospitalitas (Vol. 1).

Setioko, M. D. (2019). Analisis strategi pengembangan wisata kota di Kota Malang. Jurnal Pariwisata Pesona, 4(1), 81-88. https://doi.org/10.26905/jpp.v4i1.2524

Sobari, N. A., \& Hariyanti, P. (2017). Strategi komunikasi pemasaran terpadu (IMC) Dinas Pariwisata Provinsi Banten dalam mempromosikan pariwisata Banten. Prosiding Seminar, 65-75. Universitas Muhammadiyah Sidoarjo.

Tjiptono, F., \& Chandra, G. (2008). Pemasaran strategik. Yogyakarta: Andy Publiser.

Walikota Malang. (2014). Peraturan Walikota Malang Nomor 34 tahun 2014 tentang RencanaInduk Pengembangan Pariwisata Daerah. Kota Malang.

Walikota Malang. (2015). Peraturan Walikota Malang Nomor 40 Tahun 2015 tentang Rencana Pembangunan Jangka Menengah Daerah ( RPJMD ) Kota Malang tahun 2016. Kota 
Malang.

Yeshin, T. (1998). Integrated Marketing Communications. Oxford: The Chartered Institute of Marketing. 